\title{
Funkcjonalność zgrzewarek jako jeden z czynników decydujących o jakości połączeń zgrzewanych rur i kształtek z polietylenu
}

\begin{abstract}
Na podstawie dostępnej literatury, obowiązujących aktów normatywnych i instrukcji oraz własnych doświadczeń zostały opracowane wytyczne do oceny funkcjonalności zgrzewarek doczołowych i elektrooporowych stosowanych do łączenia rur i kształtek z tworzyw sztucznych. Jednolite wytyczne mogą przyczynić się do poprawy jakości połączeń zgrzewanych, a tym samym do zwiększenia niezawodności pracy sieci gazowych.
\end{abstract}

Słowa kluczowe: gazociąg, rury polietylenowe, zgrzewanie.

The functionality of a welding machine, as one of the factors determining the quality of welded polyethylene pipes and fittings

On the basis of the available literature, normative acts, instructions and own experiences, guidelines have been developed to assess the functionality of butt and electrofusion welding used to connect plastic pipes. Uniform guidelines can help to improve the quality of welded joints and thus increase the reliability of gas networks.

Key words: gas pipeline, polyethylene pipes, welding.

\section{Wstęp}

Zgodnie z Dyrektywą Parlamentu Europejskiego i Rady 2009/73/WE z 13 lipca 2009 r. dotyczącą wspólnych zasad rynku wewnętrznego gazu ziemnego każdy operator systemu powinien eksploatować, utrzymywać i rozbudowywać bezpieczne, niezawodne i wydajne sieci gazowe, w warunkach opłacalności ekonomicznej. Utrzymanie wysokiej jakości rurociągów z PE zależy od wielu czynników, jednym $\mathrm{z}$ nich jest proces zgrzewania, będący podstawową metodą łączenia rur i kształtek z poliolefin $[1,2,3,6]$.

Ogólne wymagania funkcjonalne dotyczące sieci gazowych z polietylenu są zawarte w normie PN-EN 12007-2:2013 [10], która określa podstawowe wymagania odnoszące się do budowy sieci gazowych z polietylenu oraz zawiera kryteria oceny jakości połączeń zgrzewanych doczołowo i elektrooporowo. Wymagania dotyczące sprzętu do wykonywania połą- czeń zgrzewanych rur i kształtek polietylenowych zawarte są w normach przywołanych w uregulowaniu prawnym 12007-2: - ISO 12176-1:2012 [7],

- ISO 12176-2:2008 [8].

Do zgrzewania gazociągów polietylenowych powinien być stosowany sprzęt posiadający potwierdzenie zgodności z określonymi wymaganiami w zakresie bezpieczeństwa oraz pozytywną ocenę funkcjonalności działania, której potwierdzeniem mogą być świadectwa kalibracji wykonywane przez upoważnione serwisy zgrzewarek. W związku z tym, że nie ma określonego - ani przez przepisy prawne, ani techniczne - zakresu badań kontrolnych, które należy przeprowadzać, zakres działań sprawdzających wykonywanych przez producentów i autoryzowane serwisy jest bardzo różny. 


\section{Opracowanie wytycznych oceny funkcjonalności zgrzewarek}

Przegląd literatury, aktów normatywnych, instrukcji obsługi zgrzewarek oraz świadectw kalibracji pozwolił na wytypowanie wymagań, jakie powinny być kontrolowane w procesie okresowej oceny funkcjonalności zgrzewarek doczołowych i elektrooporowych stosowanych do łączenia rur z tworzyw sztucznych.

Przedstawione w normie ISO 12176-1 [7] wymagania dla zgrzewarek doczołowych określają zakres badań przed wprowadzeniem do obrotu danego typu urządzenia. W obszarze badań kontrolnych (kalibracji zgrzewarki) norma nie specyfikuje parametrów, jakie należy sprawdzić. Zakres kalibracji zależy więc od producenta urządzenia lub autoryzowanego serwisu i nie zawsze uwzględnia wszystkie elementy, które mogą mieć wpływ na jakość połączenia zgrzewanego.

Do opracowania wytycznych oceny funkcjonalności zgrzewarek, spośród wymienionych w normie wymagań, wybrano te cechy, które mogą ulegać pogorszeniu podczas eksploatacji urządzenia, a mianowicie:

- kontrola urządzenia mocująco-scalającego w zakresie:

- oceny płynności ruchu elementu ruchomego,

- pomiaru czasu odsunięcia elementu ruchomego w celu wyjęcia płyty grzewczej,

- pomiaru współosiowości elementów zamocowanych w uchwytach;

- poprawność działania freza skrawającego w zakresie:

- oceny powierzchni czołowych rur po frezowaniu,

- oceny wióra po skrawaniu,

- pomiaru wielkości szczeliny pomiędzy sfrezowanymi powierzchniami dociśniętymi do siebie;

- kontrola płyty grzewczej w zakresie:

- oceny powierzchni płyty;

- kontrola systemu grzewczego w zakresie:

- sprawdzenia dokładności wskazań miernika temperatury zainstalowanego w płycie grzewczej lub urządzeniu sterującym,

- sprawdzenia układu regulacji temperatury;
- kontrola systemu realizującego docisk łączonych elementów w zakresie:

- sprawdzenia dokładności pomiaru wielkości sterującej, tj. ciśnienia w układzie hydraulicznym.

Przy realizacji procesu zgrzewania istotne jest utrzymanie stabilnych parametrów zgrzewania w całym jego cyklu. W przypadku temperatury w normie ISO 12176-1 [7] określono, że powinna ona być utrzymywana w granicach $\pm 7^{\circ} \mathrm{C}$ od wartości nastawionej. W zakresie stabilności ciśnienia norma nie zawiera wymagań. Określa jedynie dokładność przyrządu kontrolnego.

Do sprawdzenia stabilności ciśnienia można zastosować wymagania zawarte w specyfikacji DVS 2208-1 [6], tj. zmiana maksymalnego ciśnienia w czasie 30 minut nie powinna przekroczyć wartości dopuszczalnej o więcej niż 5\%. Badanie stabilności ciśnienia pozwala na ocenę szczelności układu hydraulicznego.

Norma ISO 12176-2 [7] zawiera szereg wymagań, które dotyczą głównie bezpieczeństwa obsługi. Z zakresu wymagań funkcjonalnych wybrano te, które mogą mieć bezpośredni wpływ na uzyskanie zgrzewu o wymaganej jakości oraz powinny zostać sprawdzone w wyniku okresowej kontroli. Wytypowane wymagania obejmują:

- prawidłowość działania zgrzewarki przy zmiennych parametrach zasilania,

- dokładność pomiaru temperatury otoczenia.

Podczas realizacji procesu zgrzewania elektrooporowego istotne jest utrzymanie wymaganego napięcia zasilania uzwojenia drutu oporowego kształtki na określonym poziomie i w ustalonym przedziale czasu. Norma ISO 12176-2 [8] nie zawiera jednak wymagań w tym zakresie.

Podobnie jak w przypadku wymagań funkcjonalnych dla zgrzewarek doczołowych, można wykorzystać wymagania zawarte w specyfikacji DVS 2208-1 [6]:

- dokładność pomiaru czasu zgrzewania,

- dokładność napięcia zgrzewania.

\section{Wytyczne oceny funkcjonalności zgrzewarek doczołowych}

\section{Poprawność działania urzq̨dzenia mocująco- scalającego}

\section{Plynność ruchu elementu przesuwnego}

Element ruchomy urządzenia mocująco-scalającego powinien przemieszczać się płynnie, bez zacięć i skoków. Brak płynności w ruchu może być powodem zapowietrzenia układu hydraulicznego i przyczyniać się do utrudniania prawidłowego pomiaru ciśnienia oporów ruchu. Niewłaściwa wartość oporów ruchu bezpośrednio wpływa na ostateczną siłę docisku łączonych elementów i w efekcie - na jakość połączenia. Sprawdzenie płynności ruchu należy wykonać w całym zakresie roboczym siłowników urządzenia mocująco-scalającego.

\section{Prędkość przesuwu elementu ruchomego}

Element ruchomy urządzenia mocująco-scalającego powinien przemieszczać się z prędkością gwarantującą usu- 
nięcie płyty grzewczej po upływie (wymaganego procesem technologicznym) czasu nagrzewania rur PE. Szybkie usunięcie płyty grzewczej i połączenie rozgrzanych elementów ze sobą jest jednym z warunków uzyskania zgrzewu o wymaganej wytrzymałości. Zbyt powolne przesunięcie części ruchomej zgrzewarki będzie powodowało wystudzenie uplastycznionych powierzchni łączonych elementów przed ich połączeniem i powstanie tzw. kożucha. W części znajdującej się przy krawędzi zewnętrznej i wewnętrznej łączonych elementów zostanie on wypchnięty ze zgrzewu do formowanej wypływki, jednak w części środkowej pozostanie zamknięty w strefie zgrzewu, powodując jego osłabienie.

Prędkość przesuwu elementu ruchomego urządzenia mocująco-scalającego powinna umożliwiać usunięcie płyty grzewczej w czasie zgodnym z wymaganiami tablicy 1 normy ISO 12176-1 [7]. Pomiary te należy wykonać dla rury o najmniejszej i największej średnicy.

\section{Współosiowość elementów zamocowanych w uchwytach}

Dla uzyskania połączenia zgrzewanego o wymaganej wytrzymałości konieczne jest odpowiednie ustawienie przeznaczonych do łączenia elementów względem siebie. Zbyt duże ich przesunięcie będzie powodować zmniejszenie powierzchni czynnej zgrzewu, a w ekstremalnych przypadkach powstanie karbu w strefie połączenia, co może wywoływać w perspektywie długiego okresu użytkowania pęknięcia w wyniku powolnej propagacji pęknięć. Zbyt duże przesunięcie łączonych elementów będzie powodowało powstanie wypływki o niewłaściwym kształcie. Przesunięcie elementów zamocowanych w uchwytach nie powinno przekroczyć wartości 0,2 mm [5].

\section{Poprawność dzialania freza skrawającego}

Od jakości przygotowania powierzchni czołowych do zgrzewania zależy równomierność ich kontaktu z płytą grzewczą, która ma wpływ na właściwe dostarczenie ciepła w celu ich uplastycznienia.

Po procesie frezowania powierzchnia czołowa rur powinna być gładka, a wiór ciągły. Po dociśnięciu sfrezowanych powierzchni do siebie, $\mathrm{z}$ siłą docisku zgodną z wartością wymaganą do uzyskania połączenia zgrzewanego dla danej średnicy rury, wielkość szczeliny nie powinna przekraczać wartości określonych w tablicy 2 normy ISO 12176-1 [7]. Sprawdzenie należy wykonać dla rury o najmniejszej i największej średnicy.

\section{Stan plyty grzewczej oraz poprawność dziatania systemu grzewczego}

Powierzchnia płyty grzewczej powinna być tak skonstruowana, żeby po uplastycznieniu powierzchni czołowych łą- czonych elementów i odsunięciu ich od niej roztopiony materiał nie pozostawał na jej powierzchni. Najczęściej powierzchnia płyty grzewczej pokryta jest powłoką wykonaną $\mathrm{z}$ teflonu. W wyniku niewłaściwego posługiwania się płytą może dojść do jej zarysowania, co z kolei może powodować przyklejanie się rozgrzanego polietylenu do jej powierzchni. Sprawdzenie powierzchni płyty grzewczej polega na ocenie wizualnej w celu stwierdzenia, czy nie występują ubytki w jej warstwie pokrywającej.

Gwarancją uzyskania właściwego połączenia zgrzewanego jest dostarczenie odpowiedniej ilości ciepła do czołowych powierzchni łączonych elementów, dzięki której następuje uplastycznienie materiału. Zapewnienie dostatecznej ilości ciepła zależy od czasu nagrzewania oraz temperatury płyty grzewczej. Czas zgrzewania odmierzany jest przez operatora lub automatycznie - za pomocą wbudowanego w zgrzewarce stopera. Za utrzymanie właściwej temperatury płyty grzewczej odpowiedzialny jest układ pomiaru i regulacji temperatury w zgrzewarce.

W przypadku, gdy w zgrzewarce wbudowany został stoper, wymagana jest ocena poprawności odmierzania czasu.

Poprawność działania systemu grzewczego zgrzewarki polega na:

- sprawdzeniu dokładności wskazań miernika temperatury. Maksymalna odchyłka wskazań od temperatury według przyrządu kontrolnego nie powinna wynosić więcej niż $\pm 5^{\circ} \mathrm{C}[5]$;

- sprawdzeniu układu regulacji temperatury. Temperatura powierzchni płyty grzewczej, kontrolowana w temperaturze otoczenia $23 \pm 2^{\circ} \mathrm{C}$, powinna być utrzymywana $\mathrm{w}$ granicach $\pm 7^{\circ} \mathrm{C}[5]$. W przypadku stwierdzenia niewłaściwego działania układu regulacji należy wykonać stosowne regulacje/naprawy i przeprowadzić ponowne sprawdzenie w temperaturze otoczenia: $-10^{\circ} \mathrm{C} \mathrm{i}+40^{\circ} \mathrm{C}$, dla najniższej i najwyższej temperatury zgrzewania zgodnie $\mathrm{z}$ instrukcją producenta zgrzewarki oraz w środku tego zakresu, np.: $170^{\circ} \mathrm{C}, 220^{\circ} \mathrm{C}$ i $260^{\circ} \mathrm{C}$.

\section{Poprawność dzialania systemu realizującego docisk tączonych elementów}

Jednym z parametrów warunkujących uzyskanie połączenia zgrzewanego o wymaganej wytrzymałości jest docisk łączonych elementów. Wyrażany jest on jako siła oddziałująca na jednostkę powierzchni. W zależności od rodzaju zgrzewanych tworzyw oraz stosowanej procedury zgrzewania może ona przyjmować różne wartości. W przypadku rur i kształtek z polietylenu do budowy gazociągów docisk łączonych elementów powinien wynosić $0,15 \mathrm{~N} / \mathrm{mm}^{2}$. Dla uzyskania wymaganego docisku producent zgrzewarki wyznacza, dla danej średnicy i grubości ścianek przeznaczonych do łączenia 
elementów, wymagane wartości ciśnienia w układzie hydraulicznym, uwzględniając powierzchnie czynne tłoków siłowników. W zależności od typu zgrzewarki ciśnienie mierzone jest albo przez zastosowany manometr, albo przez elektroniczny układ pomiarowy. Uzyskanie prawidłowego docisku łączonych elementów będzie więc zależeć od dokładności pomiaru ciśnienia. Zgodnie z normą ISO 12176-1 [7] wymagane jest zastosowanie miernika ciśnienia co najmniej klasy 1.

W ramach oceny funkcjonalności zgrzewarki podczas tzw. okresowej kalibracji należy wykonać sprawdzenie dokładności pomiaru ciśnienia w jej układzie hydraulicznym. Dopuszczalny błąd pomiaru nie powinien przekroczyć wartości $1 \%$ zakresu pomiarowego miernika ciśnienia [5].
Oprócz właściwego pomiaru ciśnienia zgrzewania istotne jest jego utrzymanie na stałym poziomie w określonym czasie, np. w czasie studzenia zgrzewu pod dociskiem. Zgodnie z wymaganiami specyfikacji DVS 2208-1 [6] zmiana maksymalnego ciśnienia, które może być wytworzone przez pompę hydrauliczną zgrzewarki, nie powinna przekroczyć wartości dopuszczalnej o więcej niż 5\% w czasie pomiaru trwającego 30 minut. Podstawowym warunkiem przystąpienia do tego badania jest usunięcie ewentualnych nieszczelności układu hydraulicznego, które najczęściej występują na szybkozłączach służących do podłączenia wężami hydraulicznymi agregatu z urządzeniem mocująco-scalającym.

\section{Wytyczne oceny funkcjonalności zgrzewarek elektrooporowych}

\section{Prawidłowość działania układu regulacji napięcia zasilania}

Podczas wykonywania połączeń zgrzewanych metodą elektrooporową wymagane jest zastosowanie napięcia zasilania zgodnie z wartością ustaloną przez producenta kształtki. Od wartości napięcia będzie zależało natężenie prądu w uzwojeniu kształtki o określonej rezystancji. Na skutek przepływu prądu przez uzwojenie drutu oporowego w strefie zgrzewu nastąpi wzrost temperatury powodującej uplastycznienie zewnętrznej powierzchni rury i wewnętrznej powierzchni kształtki. Za uzyskanie odpowiedniej temperatury w końcowej fazie zgrzewania odpowiedzialny jest producent kształtki, który dobiera odpowiednią rezystancję jej uzwojenia, napięcie oraz czas zgrzewania. Producent zgrzewarki odpowiada natomiast za utrzymanie w czasie zgrzewania właściwego poziomu napięcia.

Zgodnie z wymaganiami specyfikacji DVS 2208-1 [6] napięcie powinno być utrzymywane na zadanym poziomie z dokładnością 2,5\%. Sprawdzenie należy wykonać przy nominalnym napięciu zasilania zgrzewarki.

\section{Prawidlowość działania zgrzewarki przy zmiennych parametrach zasilania}

Wykonywanie połączeń zgrzewanych najczęściej odbywa się w terenie. Podczas zgrzewania wymagane jest dostarczenie energii elektrycznej, która pobierana jest głównie z agregatów prądotwórczych. W przypadku zastosowania właściwego urządzenia napięcie zasilające zgrzewarkę będzie stabilne i na odpowiednim poziomie. Zastosowanie niewłaściwego agregatu czy też zasilanie zgrzewarki długimi kablami (spadek napięcia) może powodować dostarczenie energii elektrycznej o nieodpowiednim napięciu zasilania. Zgrzewarka powinna być odporna na zakłócenia, które mogą wystąpić w sieci, a układ regulacji napięcia wyjściowego po- winien działać prawidłowo przy zmianie napięcia zasilania w zakresie $\pm 15 \%$ od wartości nominalnej [5].

\section{Poprawność pomiaru czasu zgrzewania}

Czas zgrzewania to drugi parametr, po napięciu zgrzewania, za który odpowiada zgrzewarka elektrooporowa i ma on wpływ na ilość energii, która zostanie dostarczona do połączenia. Błąd pomiaru czasu zgrzewania nie powinien być większy niż $\pm 1 \%$ [5].

\section{Poprawność pomiaru temperatury otoczenia}

Większość obecnie stosowanych zgrzewarek posiada opcję pomiaru temperatury otoczenia. Zgodnie z zaleceniami producentów kształtek elektrooporowych czas zgrzewania powinien uwzględniać temperaturę, w jakiej realizowane jest połączenie. Podawany na kształtkach czas zgrzewania najczęściej dotyczy temperatury otoczenia zbliżonej do $20^{\circ} \mathrm{C}$. Dla pozostałych temperatur otoczenia z zakresu od $30^{\circ} \mathrm{C}$ do $0^{\circ} \mathrm{C}$ na etykietach dołączanych do kształtki podawane są wartości odpowiednich czasów zgrzewania. Dla temperatur niższych czas zgrzewania jest wydłużany, a dla temperatur wyższych - skracany. Ustalenie właściwego czasu zgrzewania może dokonywać się automatycznie przez urządzenie zgrzewające. Odbywa się to na podstawie parametrów zgrzewania wprowadzonych do zgrzewarki czytnikiem z kodu kreskowego kształtki. Wówczas zgrzewarka na podstawie zmierzonej temperatury otoczenia oraz ustalonej przez producenta kształtki charakterystyki zależności czasu zgrzewania od temperatury otoczenia ustala odpowiedni czas procesu zgrzewania. Od dokładności pomiaru temperatury otoczenia będzie więc pośrednio zależała ilość energii dostarczonej do kształtki, co wpłynie na jakość połączenia zgrzewanego. Zgodnie z wymaganiami specyfikacji DVS 2208-1 [6] pomiar temperatury otoczenia powinien być realizowany z dokładnością $\pm 1^{\circ} \mathrm{C}$. 


\section{Uwaga ogólna}

Przedstawione wytyczne oceny zgrzewarek obejmują wyłącznie kontrolę parametrów, które mogą mieć wpływ na jakość połączenia zgrzewanego. Oprócz kontroli wyma- gań funkcjonalnych serwisy prowadzące kalibrację powinny również wykonywać sprawdzenie w zakresie bezpieczeństwa obsługi zgodnie ze stosownymi wytycznymi i instrukcjami.

\section{Wnioski}

Utrzymanie parametrów zgrzewania na wymaganym poziomie jest jednym z podstawowych warunków uzyskania połączenia zgrzewanego o wymaganej jakości. Sprawdzanie (kalibracja) zgrzewarek jest istotnym czynnikiem wpływającym na utrzymanie sprzętu na wymaganym poziomie technicznym. Badania kontrolne zgrzewarek powinny obejmować wszystkie parametry, które mogły ulec pogorszeniu w wyniku ich eksploatacji i wpływają na jakość wykonywanych połączeń zgrzewanych. Niektóre serwisy prowadzące okresowe sprawdzenia zgrzewarek ograniczają się do kon- troli tylko kilku wybranych parametrów, stosując duże tolerancje akceptacji wyników pomiarów, nieadekwatne do aktualnych poziomów określonych w normach, lub też oceniając tylko urządzenia pod kątem bezpieczeństwa ich obsługi.

W ramach realizacji pracy statutowej wymienionej poniżej opracowano wytyczne przeznaczone dla operatorów gazociągów, producentów zgrzewarek i autoryzowanych serwisów do potwierdzania prawidłowego funkcjonowania urządzeń zgrzewających, a tym samym do zwiększenia niezawodności pracy sieci gazowych $[2,4,5]$.

Prosimy cytować jako: Nafta-Gaz 2017, nr 12, s. 953-957, DOI: 10.18668/NG.2017.12.06

Artykuł nadesłano do Redakcji 29.08.2017 r. Zatwierdzono do druku 11.10.2017 r.

Artykuł powstał na podstawie pracy statutowej pt.: Funkcjonalność zgrzewarek jako jeden z parametrów decydujących o jakości połaczeń zgrzewanych - praca INiG - PIB na zlecenie MNiSW; nr zlecenia: 0102/GP/16, nr archiwalny: DK-4100-0102/16.

\section{Literatura}

[1] Garbacz T., Sikora J.: Przetwórstwo tworzyw polimerowych. Cz. 2. Politechnika Lubelska, Lublin 2012.

[2] Raczkowski J., Klupa A.: Bezpieczeństwo sieci gazowych z rur polietylenowych. Nafta-Gaz 1998, nr 6, s. 264-270.

[3] Szewczyk P.: Badania odporności na oddziaływania punktowe rur polietylenowych warstwowych uktadanych $w$ gruncie rodzimym, przeznaczonych do przesylania gazu. Nafta-Gaz 2012, nr 9, s. 611-616.

[4] Szewczyk P.: Określenie kryteriów do oceny możliwości zastosowania metod renowacji gazociagów stalowych do przesyłania gazu koksowniczego. Nafta-Gaz 2015, nr 8, s. 578-583.

[5] Wróblewska A.: Funkcjonalność zgrzewarek jako jeden z parametrów decydujących o jakości połaczeń zgrzewanych. Praca INiG - PIB na zlecenie MNiSW, nr zlecenia: 0102/GP/16, nr archiwalny: DK-4100-0102/16.

\section{Akty prawne i normatywne}

[6] DVS 2208-1 Welding of thermoplastics - tools and devices for the heated tool welding of pipes and piping parts.

[7] ISO 12176-1:2012 Plastics pipes and fittings. Equipment for fusion jointing polyethylene systems - Part 1: Butt fusion.
[8] ISO 12176-2:2008 Plastics pipes and fittings. Equipment for fusion jointing polyethylene systems - Part 2: Electrofusion.

[9] ISO 21307:2011 Plastics pipes and fittings. Butt fusion jointing procedures for polyethylene (PE) pipes and fittings used in the construction of gas and water distribution systems.

[10] PN-EN 12007-2:2013-02 Infrastruktura gazowa. Rurociagi o maksymalnym ciśnieniu roboczym do 16 bar włącznie. Część 2: Szczegółowe wymagania funkcjonalne dotyczace polietylenu (MOP do 10 bar wtacznie).

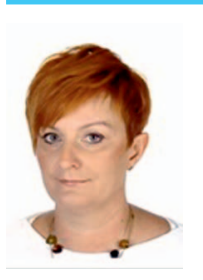

Mgr inż. Anna WRÓBLEWSKA

Starszy specjalista badawczo-techniczny w Zakładzie Przesyłania i Dystrybucji Gazu - Laboratorium Tworzyw Sztucznych. Instytut Nafty i Gazu - Państwowy Instytut Badawczy ul. Lubicz 25 A, 31-503 Kraków

E-mail: anna.wroblewska@inig.pl 